\title{
A Speech Act Analysis Of Obama's Speech: Politics And Faith
}

\author{
Kalejaiye, S. Abiola PhD \\ Babcock University, Ilisan Remo, Ogun State \\ DOI: 10.29322/IJSRP.11.08.2021.p11648 \\ http://dx.doi.org/10.29322/IJSRP.11.08.2021.p11648
}

\begin{abstract}
Politicians, in legitimising their ideologies exploit language. They consciously produce specific kinds of speech acts in order to covertly authorise their beliefs and persuade their audience. A plethora of studies exist on propositional meanings in Nigerian political speeches nonetheless a paucity exists on utterance meanings in foreign political speeches and on discordant concept of Religion and politics. Therefore, this paper investigated the kinds of speech acts Obama employed in legitimising his ideology about religion in his 2006 political speech titled Faith and Politics. The mixed method was adopted. A total of 182 sentences in the speech formed the population of the study while only 18 purposively selected sentences tagged utterances (UT) constituted the sample size of the study. Allan Speech Acts Theory was employed. The findings revealed that Obama used both direct and indirect speeches. In the direct category, the speaker used a preponderance of Constative Assertive acts 10 (94.4\%) and only $1(3.57 \%)$ directive act for affirming his beliefs about religion and the interconnection between religion and politics. However, for the indirect category, the eloquent speaker employed verdictive acts $(55.5 \%), 1(5.5 \%)$, directive requesitive acts (33.3\%) and assertive act $1(5.5 \%)$. The indirect verdictive acts were used to covertly judge the aberration of religion-its reduction to a tool of discrimination, terrorism, and manipulation of believers' minds etcetera. Obama thus, employed the directive requesitive act in imploring his listeners to turn a new leaf to religion and rather exploit religion to teach moral values-discipline, tolerance and ultimately give hope to the people thereby making religion serve as a panacea to critical social ills, and thus a veritable complement for global politics. This paper, therefore, concludes that the combination of religion and politics is required for an effective global politics. This paper recommends that religious-political discourse should not be parochial so it can cater for the needs of the pluralistic world.
\end{abstract}

Index Terms- Language, Pragmatics, Politics, Speech Acts,

\section{INTRODUCTION}

$\mathrm{G}$ enerally, the genres of religious and political discourse are not exactly under-researched. Pioneering linguistic works on religious discourse have been undertaken mainly within the framework of stylistic analysis especially regarding graphological, semantic, syntactic and morphological features that characterise the discourse (e.g. Crystal and Davy (1969) Oladosu (2003)). On the other hand, political discourse has attracted the attention of linguists from Systemic Functional Linguistics (Osisanwo 2017,
Aremu 2015, Kalejaiye 2012Opeibi 2009, Odebunmi 2008) (in Soyombo 2019). However, there is a paucity of studies on utterance meanings on the discordant concepts of religion and politics.

This paper presents a Speech Act analysis of President Barrack Obama, the first black American president's speech titled 'Politics and Faith'. It applies Allan's Speech Act model which originated from Austin 1962's notion of 'speeches are actions'. The significance of this paper is to establish and imports of the speech acts President Obama exploited in articulating the synergising the divergent concept of religion and politics.

Religion and Politics have both been adjudged divergent and yet intricately connected. Mark (2018p.1) tracing the concept to two Latin words Religio, meaning 'restraint' and Religionem, which denotes 'to show respect for something sacred, defines religion as an organised systems of beliefs and practises revolving around or leading to a transcendent spiritual experience'. This definition contrasts greatly with politics. According to Obafemi (1961 p1) 'politics is the science or the art of the managing public affairs'. Obama (2006p1) maintains that 'Politics depends on man's ability to persuade his fellow humans of common aims based on a common reality.

Despite the divergence hinted at above, religion and politics are relatable because they are both concerned with power, are both interdependent and expected to solve human problems. Buttressing the foregoing, Obafemi (ibid) posits that although they are different- religion being spiritual and politics being materialistic, nonetheless 'living man is a combination of matter and spiritand for him to be the real image of God,he must not only be well-developed and wealthy but must also function in harmony with and under the control of his spirit..'.Explicating the connection, Obama (2006 p1) averred that politics involves the compromise, the art of what's possible, but religion does not allow for compromise- It's the art of the impossible'. He affirms that religion seeks the interest of few; Politics seeks interest of all.

Language is a veritable instrument of power exploited by both politics and religion. It is not just a human vocal sound or graphic symbol via which man communicates- ideas, emotions, or achieves other communicative human purposes but an instrument of instituting and legitimising power. The foregoing is certainly true as the acquisition of power and its enforcement can be achieved in a number of ways: one of the obvious is through physical coercion, which involves the imposition of desire on a people, via force or violence- a style of leadership common with the military rule. However, in democracy, just like in religion, leaders depend on the onus of effective use of language to 
persuade people to act voluntarily in the way they want. So,religious leaders like democratic leaders 'exercise power through the manufacture of consent... or at least acquiescence towards it' (Fairclough 1989 p4).

\section{POLITICS AND PERSUASION}

The act of manufacturing power through consent is persuasion. According to the Classical tradition of rhetoric, an effective persuasion is a function of two important factors: Vir bonus-virtuous character and heuristic or logos- effective use of words Jonathan (2004). This implies that a successful political or religious speech requires effective use of language and good personality. In addition, Ozimede (1985) avers that a speaker's political success can depend largely on the way he picks his words and stings them together in a sentence, and on the acts he performs with such words and sentences(Speech acts).

\section{THEORETICAL FRAMEWORK}

\section{Speech Acts Theory}

The speech acts theory maintains that utterances are actions. Hence, words are not merely for saying but for 'doing things' or performing actions. Finnegan (2008 p283) avers that speech acts are 'actions that are carried out through language', while Yule (1996 p48) maintains that speech acts are 'the actions performed by producing utterances.' Some of the actions that utterances can achieve are: promising, threatening, reporting, requesting, convincing, advising, etcetera.

Austin (1962) the proponent of this theory, explicitly acknowledged the social or interpersonal dimension of language behaviour. By this, he meant that utterances can either be used for 'saying' or for 'doing things' in different social contexts. First, utterances can simply state (constatives) or perform (performatives) actions. Explaining the disjunction, between constatives and performatives, Austin posits that constatives are statements which function to describe some events, processes or states of affairs, and the propositions have the property of being true or false (Yule 2002).

On the contrast, performative utterances have no truth value. They are used to do something rather than to say what something is or is not (cf Lyons, 1977 p726). Instead of being true or false, performatives may be 'felicitous' or 'infelicitous.' The major difference between them as Austin posits is between 'doing' and 'saying', while constatives simply 'say' performatives perform actions

\section{Felicity Conditions}

According to Austin, there are certain expected/ appropriate circumstances technically known as felicity conditions, for the performance of a speech acts to be recognized as intended. These conditions are summarized by Austin (1962) as: Sincerity, preparatory, executive and fulfilment conditions.

Sincerity Condition denotes how sincere the speaker is with the particular illocutionary act, while preparatory condition bothers on the appropriateness of the participants of the speech acts in relation to the success of the speech event. Executive condition entails that the speech act be properly executed- else, the speech act will be infelicitous. The last is fulfilment condition; this implies that for a speech act to be felicitous, it must create the necessary effect/impact on the hearer.

Austin identifies a threefold related act that speech acts must contain. They are: locutionary, illocutionary and perlocutionary. A locutionary act according to (Yule 1996 p 48) is the basic act of utterance or production of a meaningful linguistic expression. Hence, locutionary act means linguistic denotation of an expression. However, Austin (1962) posits that illocutionary act as an act performed in saying something, that is, the action performed with the locutionary act (i.e. an utterance).The ultimately aim why a speaker utters locutionary act is to perform certain intended functions Examples of illocutionary acts include proposing, threatening, reporting, telling and asking etcetera.

Perlocutionary acts are meant to produce certain effect on the hearer. This is generally known as 'Perlocutionary effect.' Thus, Perlocutionary acts can be represented as an illocutionary act of the speaker $(\mathrm{S})$ plus its effects on the hearer $(\mathrm{H})$.

a) $\quad$ A tells $+\mathrm{B}$ believes ... $=$ A persuades $\mathrm{B}$ that ... $\mathrm{E}$ tells $+\mathrm{F}$ intends $\ldots=$ E persuades $\mathrm{F}$ to $\ldots$

From the foregoing, illocutionary acts are the means to achieving perlocutionary acts and not vice versa. Perlocutionary acts have not been investigated to the extent that illocutionary acts have been. This is because Perlocutionary acts are not intimately related to linguistic structure, semantics and communication as illocutionary acts are perlocutionary acts unlike illocutionary acts are not conventional in nature but can be achieved through conventional acts (Osisanwo.2003 p64).

Furthermore, the performance of an illocutionary act involves establishing an understanding of the meaning and the force of the locution. By convention many illocutionary acts invite a response. An order, for instance, invites obedience and a promise invites fulfilment (Austin 1962:117-118) .The distinction between these three aspects of speech acts is quite vivid in Kempson (1975:51) in Osisanwo(2003) describes the speech acts thus:

Speakers utter sentences with or particular

meaning

(locutionary act) and with a particular force (illocutionary act) in order to achieve a

certain

(perlocutionary) in the hearer). effect

Finally, Austin emphasizes the clear difference between the act of doing $X$, i.e. achieving $X$ (e.g. persuading) and 'the act of attempting to do $\mathrm{X}$ (attempting to persuade someone). He says this is a vital subject under this theory because the two acts achieve/perform different functions which convey different effects. It is this simple difference that brings about failure of linguistic communication - The hearer sometimes decodes a different meaning from what the speaker intends. How many speech acts are there and how are they expressed in language? Scholars of speech acts have postulated different speech acts. Some models are reviewed below:

Austin classifies speech acts into five categories which include verdictives, excercitives, commissives, behavities and expositions (Mey, 2001). Austin's work serves as the very basis for speech acts study. Most of the concepts he introduced have survived the test of time with only little modifications by his 
successors like John Searle, Allan, and Saddock. H. Paul Grice, K. Bach etc. Austin's contribution to speech acts theory drew the necessary attention to the crucial role of context in meaning recovery of as well as to the covert meaning in language use and the fact that some expressions are more appropriate than others in any situation of social interaction. However, this theory is not without its own shortcoming. Consequently, other frameworks have emerged. Some of these are Searle's (1969) Speech act model, Levinson (1977), Allan's model (1986), Bach and Hannish (1979) etcetera. For this study, Allan Keith's model for its clarity and aptness was adopted. The summary of the model is presented on a table below:

Figure 1: Keith Allan's Speech Acts Model.

Adapted from Osisanwo 2003

\begin{tabular}{|c|c|c|}
\hline NO & Subgroup & Membership Illustration \\
\hline $\begin{array}{l}1 . \\
\text { a. }\end{array}$ & $\begin{array}{l}\text { Constatives } \\
\text { Assertives }\end{array}$ & $\begin{array}{l}\text { Performative assertive verbs: affirm, allege, assert, avow, claim, } \\
\text { declare, deny, indicate, maintain, propound, say, state, submit. }\end{array}$ \\
\hline B & Informatives & $\begin{array}{l}\text { Performative informative verbs: advise, announce, disclose, } \\
\text { Inform, insist, notify, point out, regret, report, reveal, tell, and } \\
\text { testify. }\end{array}$ \\
\hline $\mathrm{C}$ & Retrodictives & Performative retrodictive verbs: recount, report. \\
\hline d. & Concessives & $\begin{array}{l}\text { Performative concessive verbs: acknowledge, admit, agree, allow, } \\
\text { assent, concede, concur, grant, own. }\end{array}$ \\
\hline $\mathrm{E}$ & Dissentives & Performative dissentive verbs: offer, disagree, dissent reject' \\
\hline f. & Suppositives & $\begin{array}{l}\text { Performative suppositive verbs: assume, hypothise, postulate, } \\
\text { stipulate, suppose, theorize }\end{array}$ \\
\hline g. & Constative verdicts & $\begin{array}{l}\text { Performative constative, verdictive verbs: approve, be of the } \\
\text { opinion classify, corroborate, deem fined, hold judge, rate }\end{array}$ \\
\hline 2 & $\begin{array}{l}\text { Predictives } \\
\text { Commissives }\end{array}$ & Performative predictive verbs: forecast, predict, and prophesy. \\
\hline $\begin{array}{l}3 \\
\end{array}$ & Promises & $\begin{array}{l}\text { Performative promising Verbs: swear, vow, bet, guarantee, } \\
\text { surrender }\end{array}$ \\
\hline B & Offers & Performative offering verbs: offer, propose, volunteer \\
\hline $\begin{array}{l}4 \\
a \\
b \\
c \\
d \\
e \\
f \\
g \\
i\end{array}$ & $\begin{array}{l}\text { Acknowledgements } \\
\text { Apologies } \\
\text { Condolences congratulations } \\
\text { Greeting } \\
\text { Thanks } \\
\text { Farewell } \\
\text { Acceptance of } \\
\text { Acknowledgement } \\
\text { Rejection of acknowledgement }\end{array}$ & $\begin{array}{l}\text {-Apologise } \\
\text { - Condole, console } \\
\text {-Congratulate } \\
\text {-Greet } \\
\text {-thank }\end{array}$ \\
\hline $5 a$ & Directives Requestives & $\begin{array}{l}\text { Requestive performative verbs: ask beg implore, insist, invite, } \\
\text { petition, plead, pray, solicit tell, summon, urge. }\end{array}$ \\
\hline $5 b$ & Questions & Questioning performative verbs: ask, inquire query question, quiz. \\
\hline & Requirement & $\begin{array}{l}\text { Requiring performative verbs: bid, charge command, demand, } \\
\text { dictate, direct, enjoin, instruct, order, prescribe, require }\end{array}$ \\
\hline $\mathrm{D}$ & Prohibitives & $\begin{array}{l}\text { Prohibitive performative verbs: enjoin, forbid, prohibit, proscribe, } \\
\text { restrict. }\end{array}$ \\
\hline $6 a$ & $\begin{array}{l}\text { Interpersonal } \\
\text { Authoritatives } \\
\text { Permissives }\end{array}$ & $\begin{array}{l}\text { Permissive performative verbs: agree to, allow, authorize, bless, } \\
\text { consent to, dismiss, excuse, exempt, forgive, grant, leave or } \\
\text { permission, license, pardon, permit, release, sanction }\end{array}$ \\
\hline $6 b$ & Advisories & $\begin{array}{l}\text { Advisory performative verbs: admonish advise, caution, counsel, } \\
\text { propose, recommend, suggest, urge, warn. }\end{array}$ \\
\hline
\end{tabular}




\section{Analytical Model for the Analysis}

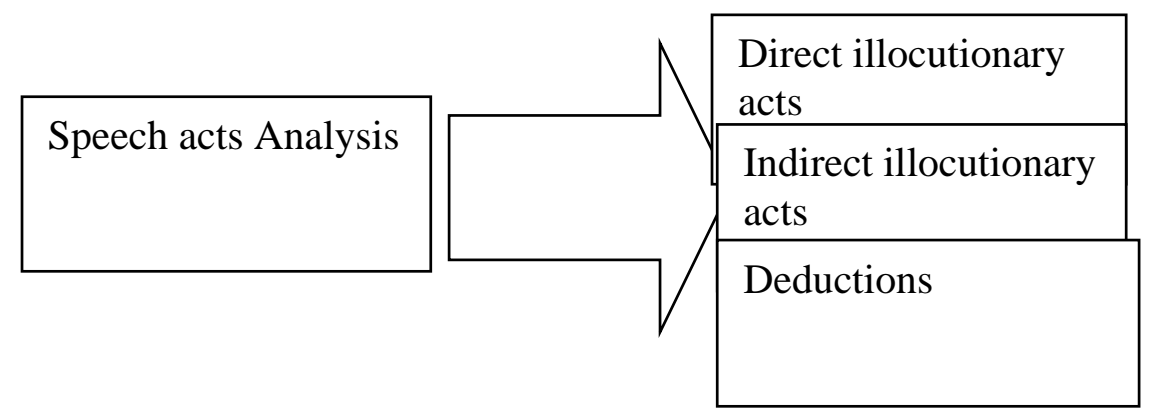

\section{Methodology}

The data is President Barrack Obama's Speech titled 'Politics and Faith'. It contains 182 sentences out of which 18 10\% sentences tagged utterance (UT)were purposively selected for their strong thematic affinity. The analysis involves identification of the direct illocutionary act, the indirect illocutionary act and discussion of the import of each of the speech acts.The mixed method was adopted. Quantitative for presenting the simple percentages of the various speech act types and qualitative for discussing the import of the choice of the speech act types.

\section{DATA ANALYSIS}

UT 1: But today I'd like to talk about the connection between religion and politics and perhaps offer some thoughts about how we can sort through some of the often bitter arguments that we've been seeing over the last several years. (Sentence3)

A.Direct illocutionary act: The utterance is a Constative 'assertive' act maintaining.

B. Indirect illocutionary act: This is, however an indirect 'verdictive'act of 'assessing' or evaluating that there has been bitter truth around the subject of 'faith' and 'politics'. C.Deductions: Obama persuades his listeners about the synergy between the politics faith and outline favourable dispositions towards the divergent concepts

UT 2: We can talk to the press, and we can discuss the religious call to address poverty and environmental stewardship all we want, but it won't have an impact unless we tackle head-on the mutual suspicion that sometimes exists between religious America and secular America.(Sentence 8)

A. Direct illocutionary act: Direct 'assertive' act of maintaining-Obama maintains that there is a mutual suspicion between religious Americans and secular Americans.

B. Indirect illocutionary act: However, it is an indirect 'verdictive' act of judging. Obama subtly affirms that the suspicion between religious Americans and secular Americans is often evaded. He adjudged that the evasion of the topics will not proffer the required solutions except the hegemony, the suspicion, the hostility between politics and faith be resolved
C. Deductions: Many eloquent speakers have glossed tactically over the subject of 'religion' because it is sensitive and controversial.

UT 3: Indeed, Mr. Keyes announced towards the end of the campaign that, "Jesus Christ would not vote for Barack Obama. Christ would not vote for Barack Obama because Barack Obama has behaved in a way that it is inconceivable for Christ to have behaved''(Sentence 10)

A. Direct illocutionary act: This is a direct 'assertive' act of 'reporting'-Obama reports Allan Keye, his antagonist.

B. Indirect illocutionary act: A Performative verdictive actAllan Keye judges Obama.

Deductions: Keye is a Christian; he detests some of Obama's ideologies and disapproves of Christian electorates voting for Obama.

UT4: Indeed, the single biggest "gap" in party affiliation among white Americans today is not between men and women, or those who reside in so-called Red States and those who reside in Blue, but between those who attend church regularly and those who don't. (Sentence17)

A. Direct act: Constative assertive act of 'affirming'.

B. Indirect act: Assertive act of 'judging'.

C. Deductions: Obama adjudges religion as the most dividing line between Americans.

UT 5: I had to take Mr Keyes seriously for he claimed to speak for my religion and my God. (Sentence 15)

A. Direct illocutionary act: A direct 'assertive' act of reporting.

B. Indirect illocutionary act: However, it is an indirect 'verdictive' act of judging. It is evident in the uses the hearsay marker, 'claimed'.

Deductions: Obama has high regards for his religion and his God. He implied that Mr Keyes submissions were his opinions and not necessarily the truth.

UT 6:Obama: I think we make mistakes, when we fail to acknowledge the power of faith in people's life. (Sentence 19).

A. Direct illocutionary act: The sentence above is an overt 'assertive' act of 'stating'.

B.Indirect illocutionary act: The illocutionary force of the utterance is, however, a verdictive performative act. Obama affirms relevance of faith to politics. 
C.Deductions: Obama says it is high time the progressives changed their disposition to religion.

UT (Obama): How should I respond? (Sentence 19)

A. Direct Illocutionary act: The propositional content of this utterance is that of directive act of 'questioning'.

B. Indirect Illocutionary act: The indirect illocutionary force intended by Obama is that of assertion -Obama indirectly asserts the convolution between religion and politics.

C. Deductions: Obama has a dilemma about religion and politics and wants his fellow progressives to see his dilemma.

UT8: Obama: Unwilling to go there, I answered with what has come to be the typically Liberal response in such debate; namely I said that we live in pluralistic society, that I cannot impose my own religious views on others that I was running to be the U.S senator of Illinois and not the minister of Illinois (Sentence 22)

A. Direct illocutionary act: This is a direct 'assertive' act of 'confessing'

B. Indirect illocutionary act: However, the above illocutionary act is an indirect 'verdictive act'.

C. Deductions: Obama's adjudged that liberal politicians including himself evade the subject of faith in politics under the guise that the society is pluralistic.

UT 9:(Obama) But Mr Keyes' implicit accusation that I was not a Christian nagged at me, and I was also aware that my answer did not accurately address the role my faith has in guiding my own values and belief (Sentence23)

A. Direct illocutionary act: A direct 'assertive' act of 'stating'.

B. Indirect illocutionary act: An indirect performative verdictive act- Obama acknowledges that his answer did not adequately address the role his faith has in guiding his values and beliefs

C. C.Deductions: Obama's regrets his prior ineptitude and admits to throw more lights.

UT 10: Conservative leaders have been all too happy to exploit this gap, consistently reminding evangelical Christians that Democrats disrespect their values and dislike their Church.(Sentence 28)

A. Direct act: Constative assertive act of 'affirming'.

B. Indirect act: Assertive act of 'judging'.

C. Deductions: Obama evaluates conservatives leaders as happy exploiters of religion.

UT11: (Obama) I was urged by some of my liberal supporters not to take this statement

seriously, to essentially ignore it. (Sentence 37 )

A. Direct illocutionary act: This is a direct 'assertive' act of 'reporting'

B. Indirect illocutionary act: The indirect Performative above is an indirect

'disputative' act of 'objecting'.

C. Deductions: The illocutionary force above brings about a pragmatic implicature. It can be inferred that Obama disagrees with the advice of his coliberal and wishes to elucidate the issues raised so as not to destroy hisreligious- political

public-

image.

45)

UT12: I confronted my own spiritual dilemma. (Sentence

Direct act: Constative 'assertive' act of declaring, confessing

A. Indirect act: Directive 'requestive' act of imploring.

B. Deduction: Obama implores the progressive to admit their spiritual dilemma and accept the advantages that exist in synergising politics and faith.

UT 13:(Obama) I came to realise something was missing. (Sentence 48)

A. Direct act: Constative assertive act of confessing.

B. Indirect act: Directive 'requestive' act of imploring.

C. Deductions: It can be deduced that at a point in time Obama did not know that spiritual rebirth was missing in his life but when he knew, he was sincere enough to put it in place and he indirectly implores his listeners to do the same.

UT14: Obama: I believed and still believe in the power of African-American tradition to spur social change. (Sentence 51)

A. Direct act: Constative 'assertive' act of affirming/ maintaining. B.Indirect act: Directive 'requestive' act Obama indirectly implores his listeners.

C.Deductions: Obama is African-American who wishes his listeners would appreciate the same orientation.

UT15:Obama: Democracy demands that the religiously motivated translate their concerns into universal, rather than religion-specific, values (Sentence126)

Illocutionary act

A. Direct act: Constative 'assertive' act of stating

B. Indirect act: Constative 'verdictive' act of judging

C. Deduction: it can be deduced that religion is adjudged parochial and incapable of handling state matters.

UT16: No matter how religious they may or may not be, people are tired of seeing faith used as a tool of attack. They don't want faith used to belittle or to divide. They're tired of hearing folks deliver more screed than sermon.(Sentences159-160)

A Direct act: Constative 'assertive' act of affirming/ maintaining. B Indirect act: Directive 'requestive' act Obama indirectly implores his listeners to turn a new leaf to religion.

C.Deductions: It can be deduced that religion is being reduced to a tool of attacking belittling and causing division in the society.

UT 17:I was able to see faith as more than just a comfort to the weary or a hedge against death, but rather as an active, palpable agent in the world. ..As a source of hope.

A Direct act: Constative 'assertive' act of affirming/ maintaining.

B Indirect act: Directive 'requestive' act .

C.Deductions: Obama urges his hearers to ensure that religion in the world today be used as means of giving hope and not a means of destroying hope particularly the hopes of unbelievers. The speakers cries for a equal proportion/a balance of faith and fairness in today's religion A hope that we can live with one another in a way that reconciles the beliefs of each with the good of all.

UT 18: A hope that we can live with one another in a way that reconciles the beliefs of each with the good of all. (Sentence 182).

A Direct act: Constative 'assertive' act of affirming/ maintaining. 
B Indirect act: Directive 'requestive' act of imploring.

C.Deduction: Obama implores every religious person to be tolerant

kind to their fellow man including unbelievers.

\section{DISCUSSION OF FINDINGS}

From the analysis, it is evident that Obama employed both direct and indirect speech acts. He employed: 17(94.4\%)direct assertive acts and 1(3.57\%) directive act. On the other hand, The plethora of the direct assertives denotes that President Obama mainly committed himself overtly to the truth of his beliefs about religion and politics. One instance is his beliefthat religion is close-minded and seeks interest ofa closed sec, while politics seeks the interse of allt. The percentage of theindirect directive act revealed he did not issue explicit imperatives, implying that he was polite in his speech.

Result on the indirect Speech Acts revealed that Obama employed10(55.5\%)verdictive acts,6(33.3\%) requestive acts, $1(5.5 \%)$ assertive acts1(5.5\%)disputative acts. The indirect verdictive were indeed used by Obama tocovertlyjudgetheaberration of religion-its reduction to a tool of discrimination, terrorism, manipulation of believer's mind etcetera.Obama indirectly asserted and disputed such abnormalities about religion and implores his listeners to turn a new leaf to religion and rather exploit it toteach discipline, moral values, tolerance and ultimately to exploit it to give hope to the people thereby employing it as a panacea to critical social ills, thus function asa complement to politics.

\section{CONCLUSION}

This study has investigated the speech acts types in President Barrack Obama's 2006 speech titled 'Faith and Politics' with a view to establishing their pragmatic imports. The study established that Obama exploited mainly direct assertive acts and indirect verdictives, as well as requesitives acts. The assertives overtly signified his beliefs about religion and politics, whilethe indirect verdictives, acts were used to covertly condemnthe illicit exploitation of religion and the requesitivesforimploration for a change of attitude towards religion. This paper agrees with both Awolowo (1961) and Obama (2006)thatthe combination ofreligion and politics; our faith, facts and fiction(Falola 2019) is required for an effective democracy and governance. .

\section{RECOMMENDATIONS}

This paper recommends that religious- political discourse should not be parochial so it can cater for the needs of the pluralistic world. Religious adherents and politicians should borrowfrom each other's language and spirit to produce utterances that are courteous, considerate, moral, invaluable, and tolerantenough to promote mutual interest of all men-believers and unbelievers.

\section{REFERENCES}

[1] Austin, J. L. (1962). Philosophical Papers. Oxford: Oxford University Press.

[2] Obafemi, A. (1961) Politics and Religion: A Lecture Given by Chief Obafemi Awolowo to

[3] Students at the Adventist College of West Africa at Ilisan Remo on the 27th January, 1961.

[4] Bach, K. and Harnish (1979) Linguistic Communication and Speech Acts. Cambridge: M. I. T. Press.

[5] Fairclough, N. (1989) Language and Power. London: Longman.

[6] Crystal D and David, D (1969). Investigating English Style. London: Longman

[7] Falola, O. (2019) Faith, Fact and Fiction: A Lecture Delivered by Falola Oluwatoyin at to the Phoenix Graduating Class of 2019 at Babcock University,

[8] Grundy, P. (2008) Doing Pragmatics. U.K: Hooder Education.

[9] Harrison, M. (2009) Barrack Obama's Speeches on the Road to the White House. Nigeria; Living Word Publishing Ministries.

[10] Jason J. (2004) Language, Society and Power London: Rout ledge.

[11] Jonathan C. B. (2005) Politician and Rhetoric; the persuasive power of metaphor. New York. Macmillan.

[12] Kasher, A. (1998) Critical Concepts (vol. 1) Route ledge (London)

[13] Bach and Hannish (1979). Linguistic Communication and speech Acts: MIT

[14] Lakoff, G. (1970) 'Linguistics and Natural Logic' Synthese, 22, 151 - 271.

[15] Lawal, A. (2003) Stylistics in Theory and Practice. Ilorin: Paragon Books.

[16] Leech G. (1994)Principle of Pragmatics. London: Longman Inc., 1994.

[17] Levinson, S. (2008).Pragmatics. Cambridge: Cambridge University Press.

[18] Mark, J.J (2018). Definition of Religion. Rerieved from www.ancient.euon 13/6/2019 from Mey, J (2001).Pragmatics: An Introduction. Blackwell.

[19] Oladosu, A.G. (2003). A Stylistic Analysis of the Quranic Verse of the Throne. In Lawal A. (ed). (2003). Stylistic Theory and Practice, Ilorin: Paragon Books

[20] Osisanwo, W. (2003) Introduction to Discourse Analysis and Pragmatics. Lagos: Femolus-Fetop Publisher.

[21] Ozimede, M (1985). Rhetorics and Political Communication as speech Act. Review of English and Literary Studies, Vol.2. No.2

[22] Peccei, S. (2002) Pragmatics. London: Routledge.

[23] Searle J. (1971) Expression and Meaning. Studies in the Theory ofSpeech Acts.

[24] Cambridge: Cambridge University Press.

[25] Soyombo, M. (2019) Linguistic Missiles in Political News Reporting in Selected Nigerian Newspaper. An Unpublished Phd Thesis. Department of Languages and Literary Studies: Babcock University.

\section{AUTHORS}

First Author - Kalejaiye, S. Abiola PhD., Babcock University, Ilisan Remo, Ogun State., Email:KalejaiyeAb@babcock.edu.ng Phone number: 07067011470 